\title{
Visualisasi Data Penduduk Dalam Membangun E-government Berbasis Sistem Informasi Geografis (GIS)
}

\author{
Kurniawan $^{[1]^{*}}$, Darius Antoni ${ }^{[2]}$ \\ Fakultas Ilmu Komputer Universitas Bina Darma ${ }^{[1], \text { [2] }}$ \\ J1. Jenderal A. Yani No. 3 Palembang, Sumatera Selatan, Indonesia \\ kurniawan@binadarma.ac.id ${ }^{[1]}$, dariusantoni@gmail.com ${ }^{[2]}$
}

\begin{abstract}
Kelurahan 16 Ulu is one of the areas in the city of Palembang which has an area of $475 \mathrm{Ha}$ and consists of several RT. Citizen data collection is the main task of a RT head. The process of managing citizen data by the head of the RT at Kelurahan 16 ulu is still using manualmethod so to get and search information about citizen spread point and data mapping cost a lot of time cause the data still in family card, and the data not yet in mapping state. To solve this problem, it needs visually show the mapping based on Geographic Information System (GIS). GIS is able to manage data that have spatial references for purposes related to mapping and planning. The resulting mapping visualization is in the form of E-government based on GIS. So that it can help to find out the citizen spread point and improve effectiveness and performance in service to the citizen.
\end{abstract}

\section{Keywords : GIS, E-goverment and mapping}

Abstrak - Kelurahan 16 Ulu merupakan salah satu wilayah di kota Palembang yang mempunyai luas wilayah yaitu $475 \mathrm{Ha}$ dan terdiri dari beberapa Rukun Tetangga (RT). Pendataan penduduk menjadi tugas pokok seorang ketua RT. Proses pengolahan data penduduk oleh ketua RT di wilayah Kelurahan 16 Ulu masih dilakukan secara manual sehingga untuk mendapatkan dan mencari infornasi mengenai titik persebaran penduduk dan pemetaan data penduduk masih membutuhkan waktu karena penyajian data yang masih berbentuk dalam lembaran Kartu Keluarga (KK) serta belum adanya penyajiaan dalam bentuk pemetaan. Untuk menyelesaikan masalah tersebut dibutuhkan sistem informasi yang dapat menampilkan visualisasi pemetaan menggunakan Geographic Information Systems (GIS). GIS mampu mengelola data yang mempunyai referensi keruangan untuk tujuan yang berkaitan dengan pemetaan dan perencaan. Visualisasi pemetaan yang dihasilkan yaitu berupa E-government berbasis GIS, sehingga dapat membantu untuk mengetahui pesebaran penduduk dan meningkatkan efektivitas dan kinerja dalam pelayanan terhadap masyarakat.

\section{Kata Kunci : GIS, E-goverment dan Pemetaan}

\section{PENDAHULUAN}

Kehadiran Teknologi Informasi dan Komunikasi (TIK) telah mengubah cara interaksi antara pemerintah dengan masyarakat dan hal ini telah membawa pada pengembangan fenomena baru yang disebut dengan e-Government[1]. E- government dapat didefinisikan sebagai seluruh tindakan dalam sektor publik (baik pusat maupun daerah) yang melibatkan teknologi informasi dan komunikasi dengan tujuan mengoptimalkan proses pelayanan publik yang efisien, transparan, dan efektif telah menjadi bagian penting dalam usaha untuk membangun tata pemerintahan yang baik (good governance) di Indonesia[2]. Penerapan teknologi informasi memberikan pengaruh yang cukup besar terhadap sektor pelayanan publik. Begitu besarnya manfaat yang diberikan oleh teknologi informasi mendorong pemerintah untuk meningkatkan penggunaan teknologi informasi dalam setiap aktivitas terutama terkait dengan pendataan penduduk. Penerapan teknologi juga telah dilakukan oleh Badan Pusat Statistik (BPS) untuk keperluan sensus penduduk. Sensus penduduk dilakukan oleh BPS dilakukan setiap sepuluh tahun sekali. Sistem yang digunakan oleh BPS memberikan informasi jumlah data penduduk disuatu wilayah tertentu tetapi tidak memetakan lokasi sebaran penduduk secara spesifik termasuk ditingkat kelurahan. Pendataan penduduk menjadi hal yang sangat penting di pemerintahan baik tingkat kelurahan, kecamatan maupun pemerintah daerah.

Kelurahan Enam-belas Ulu merupakan salah satu wilayah di kota Palembang yang mempunyai luas wilayah sebesar 475 Ha. Wilayah Kelurahan Enam-belas Ulu terdiri dari 75 Rukun Tetangga (RT). Pelayanan masyarakat yang berkaitan dengan pendataan penduduk dimulai dari tingkat RT. Saat ini pendataan penduduk di tingkat RT di kelurahan Enam-belas Ulu masih dilakukan secara manual dimana ketua RT mencatat data penduduk dan menyimpan selembar kertas Kartu Keluarga (KK). Cara tersebut menyebabkan data penduduk menjadi tidak terorganisir sehingga proses pencarian informasi serta pengamatan mengenai titik penyebaran penduduk membutukan waktu yang cukup lama. Selain itu, belum ada informasi valid yang bisa di akses secara langsung oleh pemerintah untuk mendapatkan informasi titik lokasi penduduk karena belum tersedia penyajian data dengan menggunakan visualisasi pemetaan.

Visualisasi didefinisikan sebagai suatu metode untuk memrepresentasikan suatu data atau permasalahan ke dalam format grafik atau bentuk gambar yang mudah untuk dipahami [4]. Visualisasi data dalam bentuk gambar dan grafik akan memberikan kemudahan dalam membaca dan memahami data tersebut. Salah satu bentuk visualisasi yaitu pemetaan. Adapun bidang yang berkaitan dengan visualisasi 
yaitu GIS.

Geographic Information Systems (GIS) atau Sistem Informasi Geografis dapat digunakan untuk mengatasi masalah berkaitan dengan pemetaan. SIG dibuat dengan menggunakan informasi yang berasal dari pengolahan sejumlah data, yaitu data geografis atau data yang berkaitan dengan posisi obyek di permukaan bumi[5]. Untuk memecahkan masalah dalam membangun suatu $E$ government berbasis GIS adalah membuat sistem visualisasi data penduduk yang dapat digunakan oleh ketua RT dan masyarakat untuk mendapatkan informasi titik lokasi penyebaran penduduk di wilayahnya. Sistem ini dapat membantu pemerintah dalam melakukan pengamatan persebaran penduduk di kelurahan Enam-belas Ulu. Pemantauan data persebaran penduduk oleh kelurahan dapat dilakukan melalui sistem ini sehingga informasi penduduk di daerah tersebut dapat diperoleh secara cepat dan akurat.

\section{METODE PENELITIAN}

Metode penelitian adalah tahapan yang dilaksanakan sebagai bagian dari kegiatan penelitian dalam upaya untuk mengumpulkan data atau informasi serta melakukan observasi dan investigasi pada data dan informasi tersebut.

\section{A. Metode Pengembangan Sistem}

Metode pengembangan sistem yang digunakan dalam penelitian ini adalah metode Waterfall. Metode waterfall adalah model klasik yang bersifat sistematis, berurutan dalam membangun software karena tahap demi tahap yang dilalui harus menunggu selesainnya tahap sebelumnya dan berjalan berurutan [6]. Metode waterfall disebut juga sebagai model sekuensial linier (sequential linear) atau alur hidup klasik (classic life cycle) [7]. Adapun metode waterfall terdiri dari 5 (lima) tahapan-tahapan yaitu sebagai berikut[8]:

\section{1) Analisis}

Fase ini merupakan fase pengumpulan dan analisis terhadap kebutuhan sistem yang akan dibangun, yang meliputi kebutuhan pengguna (user), kebutuhan perangkat lunak (software) dan kebutuhan perangkat keras (hardware), serta kebutuhan akan alur proses sistem.

2) Desain

Fase ini merupakan fase perancangan yang berfokus pada perancangan struktur data, dan tampilan interface pada software yang akan dibangun atau dikembangkan.

3) Pengkodean

Fase ini merupakan fase pengkonversian, dimana rancangan yang telah dibuat diterjemahkan kedalam bahasa pemrograman melalui proses coding, agar rancangan dapat dibaca dan dimengerti oleh mesin (komputer).

4) Pengujian

Testing adalah fase pengujian, yang dilakukan untuk mengetahui apakah sistem telah berjalan sesuai dengan prosedur atau tidak, memastikan sistem terhindar dari kesalahan yang terjadi, dan memastikan dalam proses input menghasilkan output yang sesuai.

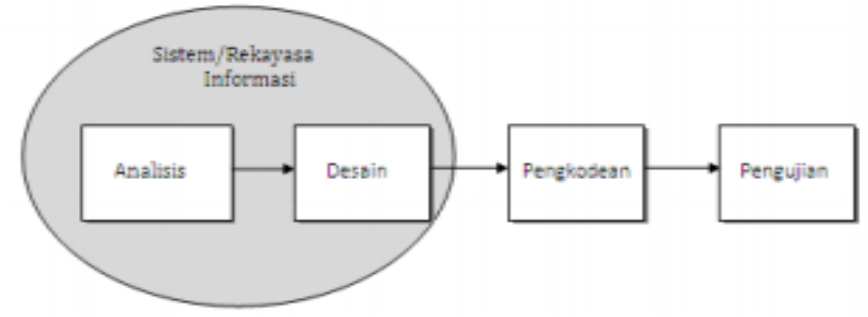

Gambar 1. Ilustasi Metode Waterfall

\section{B. Metode Pengumpulan Data}

Metode pengumpulan data yang digunakan adalah sebagai berikut:

1) Interview (Wawancara)

Interview merupakan teknik pengumpulan data dengan melakukan pertemuan dengan narasumber untuk bertukar informasi dan ide melalui tanya jawab, sehingga dapat dikonstruksikan makna dalam suatu topik tertentu.

\section{2) Studi Pustaka}

Studi pustaka dilakukan untuk memperoleh informasi dan memperkaya pengetahuan mengenai berbagai konsep yang akan digunakan sebagai dasar pedoman dalam melakukan penelitian.

\section{Penelitian Terdahulu}

Penelitian terkait dengan pemetaan maupun penelitian mengenai pemanfaatan sistem informasi geografis pada pembangunan E-goverment sudah banyak dilakukan. Salah satu penelitian pemetaan yaitu Penelitian dengan judul Pemetaan Industri Kecil Menengah (IKM) Kabupaten Bantul Berbasis Sistem Informasi Geografis. Penelitian ini mengimplementasikan arsitektur Sistem Informasi Geografis dalam merancang sebuah aplikasi. Dalam implementasinya, SIG dapat digunakan sebagai alat bantu penyampaian informasi mengenai lokasi tempat, memberikan penjelasan tentang suatu peristiwa, membuat peramalan kejadian, dan perencanaan strategis lainnya. Dengan menggunakan fasilitas Google Map pemetaandilakukan dengan memberikan icon yang berbeda untuk tiap-tiap jenis sehingga sebaran terlihat[5].

Penelitian lain yang berkaitan dengan pemetaan adalah penelitian dengan judul Sistem Informasi Geografis Populasi Penduduk Di Dusun Tegal Kenongo, Tirtonirmolo, Kasihan, Bantul, Yogyakarta. Penelitian ini membangun sistem informasi geografis dan berdasarkan pengujian yang dilakukan dengan metode black box test alpha test, menunjukkan hasil bahwa sistem informasi telah memuhi spesifikasi dan batasan yang telah ditentukan serta dapat berjalan dengan baik. Hasil penelitian menunjukkan bahwa Sistem Informasi Geografis yang dibangun dapat membantu para pengurus dusun dan warga dalam mengidentifikasi penduduk yang tinggal dan menetap di dusun Tegal Kenongo Tirtonirmolo, Kasihan, Bantul, Yogyakarta[9]. 


\section{HASIL DAN PEMBAHASAN}

Penelitian ini menghasilkan sebuah Sistem E-government berbasis GIS yang merupakan visualisasi data penduduk yang dapat digunakan untuk memudahkan pemerintah setempat dalam mengolah, mengakses dan mendapatkan informasi tentang penduduk yang disertai dengan detail profil penduduk.

Tahapan yang dilakukan pada penelitian ini adalah tahap analisis sistem, desain sistem, pengkodean dan testing. Berikut ini tahap pelaksanaan penelitian yang dilakukan untuk memperoleh sistem yang sesuai dengan tujuan penelitian.

\section{A. Analisis Sistem}

Analis yang dilakukan meliputi analisis sistem yang berjalan, analisis sistem yang diusulkan serta analisis kebutuhan sistem.

\section{1) Analisis Sistem yang berjalan}

Sistem yang berjalan saat ini masih dilakukan secara manual yaitu dimana ketua RT menyimpan data Kartu Keluarga setiap penduduk yang tinggal di RT tersebut dan menulis ringkasan data penduduk di buku milik masingmasing ketua RT. Ketua RT yang membutuhkan data penduduknya harus mencari Kartu Keluarga atau membuka ringkasan data penduduk milik ketua RT. Untuk mengetahui lokasi penduduk tersebut ketua RT harus mendatangi secara langsung penduduk yang bersangkutan. Belum adanya sistem pemvisualisasi data penduduk sehingga terdapat kesulitan dalam mengetahui penyebaran titik lokasi penduduk yang sesuai dengan data.

\section{2) Analisi Sistem yang diusulkan}

Adapun sistem yang diusulkan yaitu sebuah sistem visualisasian pemetaan data penduduk yang dapat diakses dan digunakan oleh bagian pemerintah setempat. Melalui sistem ini, pemerintah dapat mengolah dan mengakses data penduduk serta mengetahui titik lokasi penyebaran data penduduk secara langsung sesuai dengan kategori informasi yang diinginkan.

\section{3) Analisis Kebutuhan Sistem}

Analisis kebutuhan sistem yang akan dibangun terdiri dari kebutuhan fungsional dan kebutuhan non fungsional. Kebutuhan fungsional dari sistem yang akan dibangun adalah sebagai berikut:

- Sistem dapat menampilkan peta data penduduk wilayah RT di kelurahan Enam-belas Ulu yang ditampilkan berdasarkan kategori tertentu.

- Sistem dapat menampilkan daftar penduduk yang tinggal di wilayah tersebut.

Adapun kebutuhan non-fungsional sistem yang akan dibangun adalah sebagai berikut:

a) Operasional

Berdasarkan operasional meliputi:

- Dapat dijalankan pada operasi windows

- Menggunakan geoserver sebagai server pengolahan peta pada sistem

- Menggunakan MySQL sebagai penyimpanan database
- Dapat dijalankan diberbagai browser terutama Google Chrome dan Mozilla Firefox

\section{b) Keamanan}

Pengolahan data penduduk baik penambahan maupun penghapusan yang diolah oleh admin telah dilengkapi dengan halaman login sebagai akses pengguna sistem, sehingga tidak semua orang bisa menggunakan sistem.

c) Informasi

Pada sistem menyediakan informasi tentang data penduduk dan pemetaannya.

d) Kinerja Sistem

Berdasarkan kinerja sistem meliputi:

- Waktu yang digunakan untuk menampilkan peta tergantung dari kecepatan akses internet pengguna.

- Sistem dapat menyimpan data dalam jumlah yang banyak.

Pada penelitian ini pengguna (user) dari sistem yang akan dibangun terdiri dari yaitu pengujung dan admin/RT. Deskripsi dari user pada sistem ini adalah sebagai berikut:

TABEL I. DESKRIPSI KEBUTUHAN USER

\begin{tabular}{|c|c|}
\hline Pengguna & Deskripsi \\
\hline Pengunjung & $\begin{array}{l}\text { 1. Melihat visualisasi peta data penduduk dan } \\
\text { informasi rincian data peta } \\
\text { 2. Melihat grafik dana bantuan }\end{array}$ \\
\hline Admin/RT & $\begin{array}{l}\text { 1. Melakukan login dengan memasukkan } \\
\text { username dan password } \\
\text { 2. Membuka halaman peta wilayah } \\
\text { 3. Melihat titik pesebaran data penduduk } \\
\text { berdasarkan kategorinya } \\
\text { 4. Mengolah data penduduk }\end{array}$ \\
\hline
\end{tabular}

\section{B. Desain Sistem}

Desain sistem digambarkan melalui bahasa permodelan menggunakan notasi dari Unified Modelling Langguage (UML).

\section{1) Use Case Diagram}

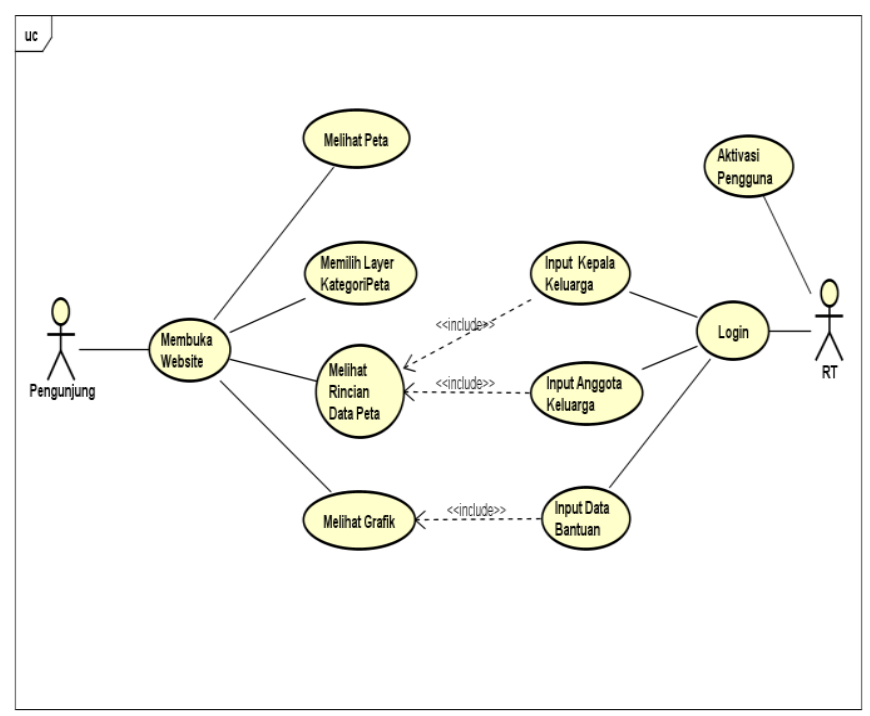

Gambar 2. Use Case Diagram 
Pada Gambar. 2 diketahui bahwa pada sistem ini terdapat dua aktor yang menggunakan sistem yaitu aktor pengunjung dan RT, dimana pada use case bahwa untuk pengunjung dapat melihat peta, memilih layer kategori peta, melihat rincian data peta yang mana berisi data peududuk dan melihat grafik bantuan penduduk. Sedangkan, RT dapat melakukan aktivasi pengguna yang nantinya dijadikan sebagai akses untuk masuk ke halaman RT. Dengan akses tersebut RT dapat melakukan input data penduduk yang berupa data kepala keluarga dan juga data anggota keluarga serta memasukkan data bantuan penduduk.

\section{2) Activity Diagram}

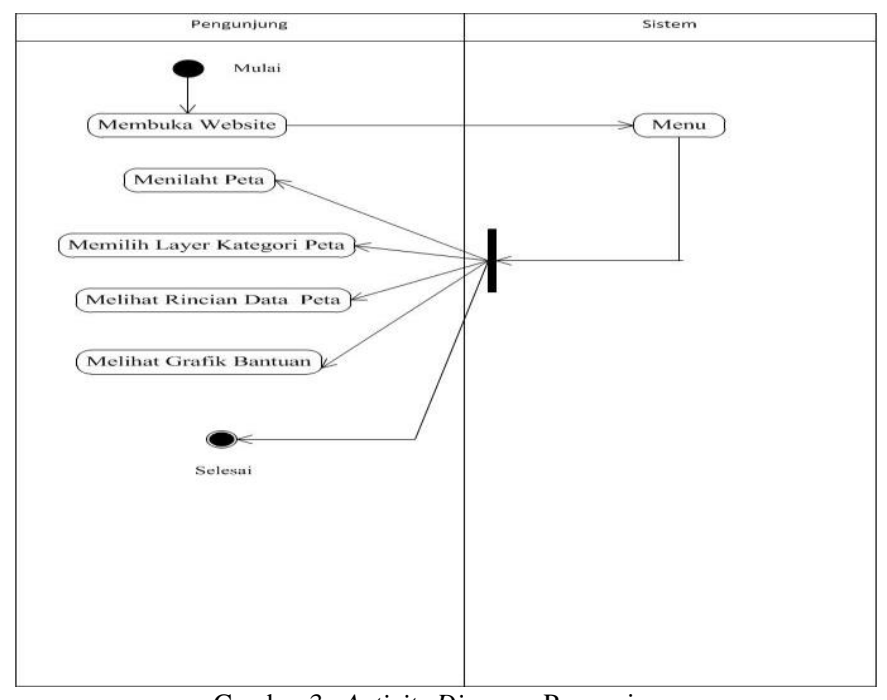

Gambar 3. Activity Diagram Pengunjung

Pada Gambar. 3 menjelaskan bahwa proses sistem dimulai dari pengunjung yang membuka website. Setelah website tampil maka pengujung dapat melihat peta, kemudian memilih layer kategori peta yang akan ditampilkan, melihat rincian peta yang berupa data penduduk dari satiap peta dan melihat grafik bantuan penduduk.

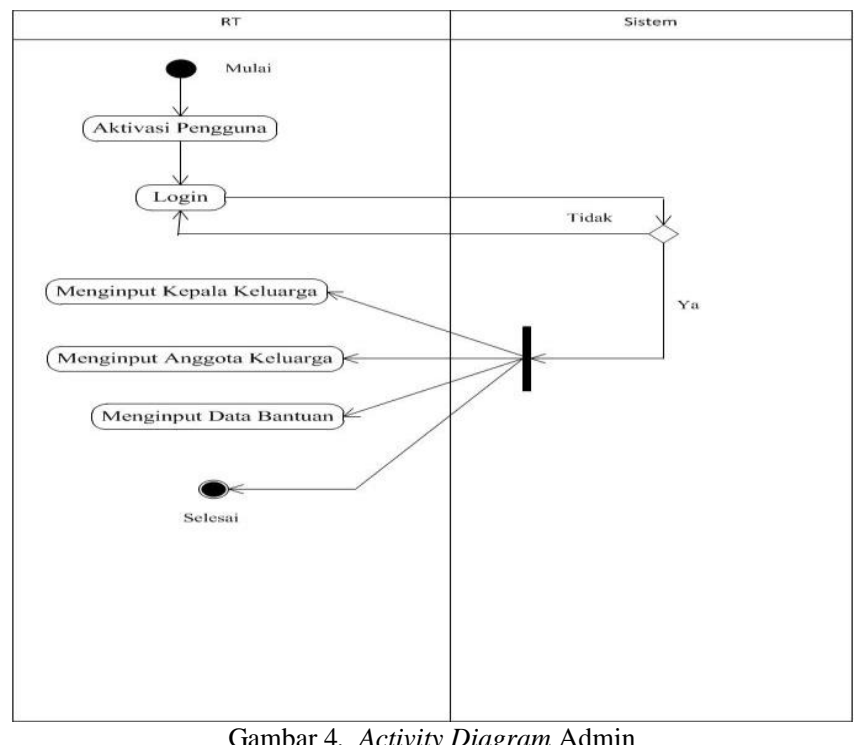

Gambar 4. Activity Diagram Admin
Pada Gambar.4 menjelaskan bahwa proses di mulai dari RT, dimana RT melakukan aktivasi pengguna agar mendapatkan akses ke dalam halaman RT. Kemudian RT melakukan login dengan menggunakan NIK dan password yang telah di daftarkan. Setelah itu, RT dapat melakukan aktivitas pada sistem seperti melakukan input data kepala keluarga, input data anggota keluarga, dan input data bantuan penduduk.

\section{Pengkodean}

Hasil dari tahap pengkodeaan yaitu berupa tampilan antarmuka/interface sistem yang merupakan hasil dari implementasi rancangan sistem yang diterjemahkan ke dalam bahasa pemrograman.

1) Tampilan Interface Pengunjung

Antar muka pengunjung terdiri dari halaman index dan halaman peta.

a) Halaman Index

Merupakan halaman awal saat sistem dibuka, dimana pada halaman ini akan tampil peta wilayah kelurahan 16 Ulu Palembang.

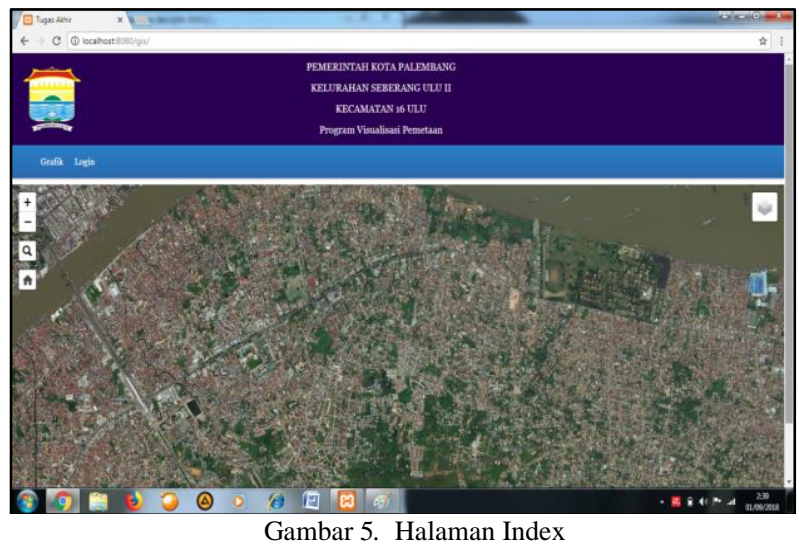

b) Halaman Peta

Pada halaman peta, jenis peta dibagi berdasarkan tampilannya, yang terdiri dari kategori rumah penduduk, bantuan KKS, bantuan KIP, bantuan KIS, jenis agama, jenis pendidikan dan jenis pekerjaan. Berikut merupakan tampilan halaman peta berdasarkan setiap kategorinya yang dapat dilihat pada gambar. 6 dibawah ini:

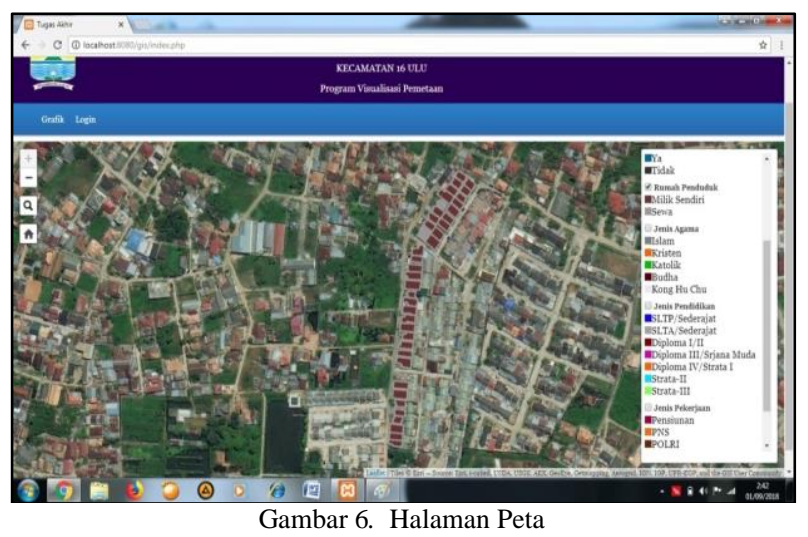




\section{c) Halaman Rincian Data Penduduk}

Pada halaman ini berisi profil penduduk beserta anggota keluarga. Data yang yang ditampilkan berupa nama, nik, alamat, nomor rumah, jenis kelamin, tanggal lahir, pendidikan, agama, statur perkawinan, pekerjaan, hubungan keluarga, jumlah anggota keluarga, bantuan KKS, bantuan KIP, bantuan KIS dan jenis rumah yang akan tampil sesuai dengan peta rumah yang dipilih. Tampilan halaman rincian data penduduk dapat dilihat pada gambar. 7 berikut ini:

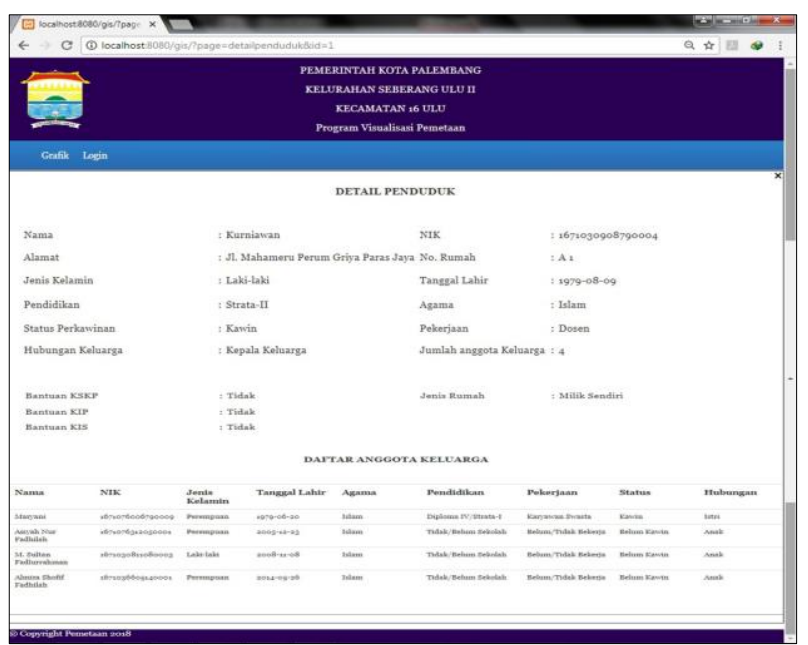

Gambar 7. Halaman Rincian Data Penduduk

\section{d) Halaman Grafik}

Merupakan halaman yang menampilkan grafik dari jumlah data penduduk yang mendapatkan bantuan dari pemerintah. Grafik bantuan ini terdiri dari grafik bantuan KKS, grafik bantuan KIP dan grafik bantuan KIS, pada gambar. 8 dapat dilihat gambar dari halaman grafik bantuan sebagai berikut:

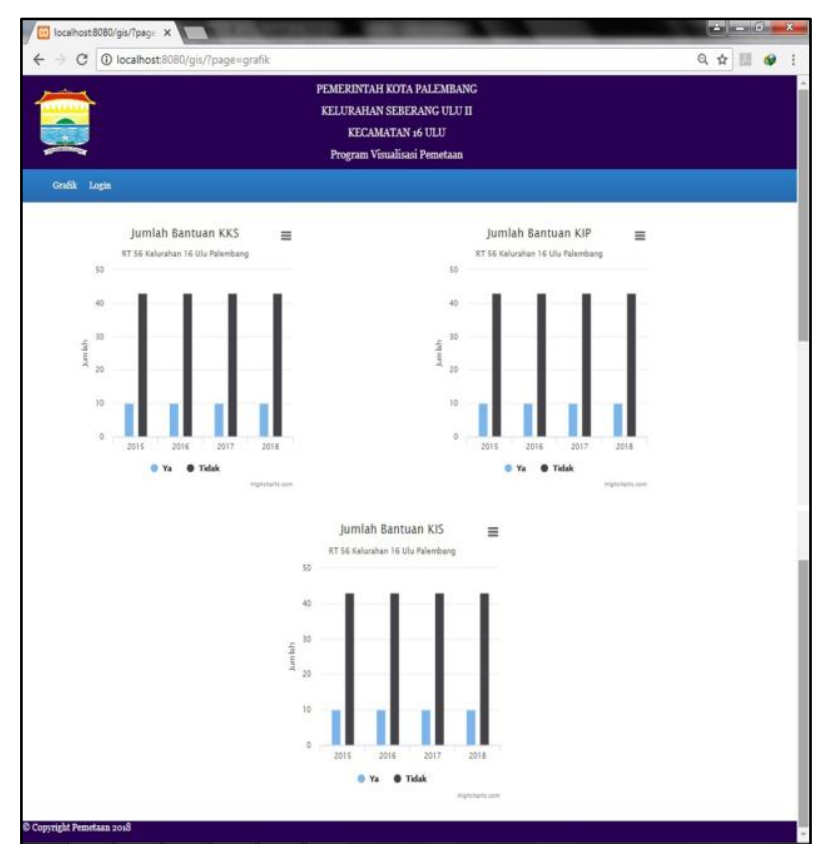

Gambar 8. Halaman Grafik
2) Tampilan Interface Admin/RT

Tampilan ini merupakan interface khusus admin/ RT. Adapun halaman yang akan ditampilkan yaitu Halaman Login, Halaman Home, Halama Form Penduduk, Halaman Data Penduduk dan Halaman Anggota Keluarga.

a) Halaman Login

Pada halaman ini user harus memasukkan username dan password sebagai akses. Jika data yang dimasukkan valid maka user akan masuk kedalam halaman home user. Apabila tidak maka sistem akan menampilkan halaman login kembali. Halaman login dapat dilihat pada gambar. 9 seperti berikut ini:

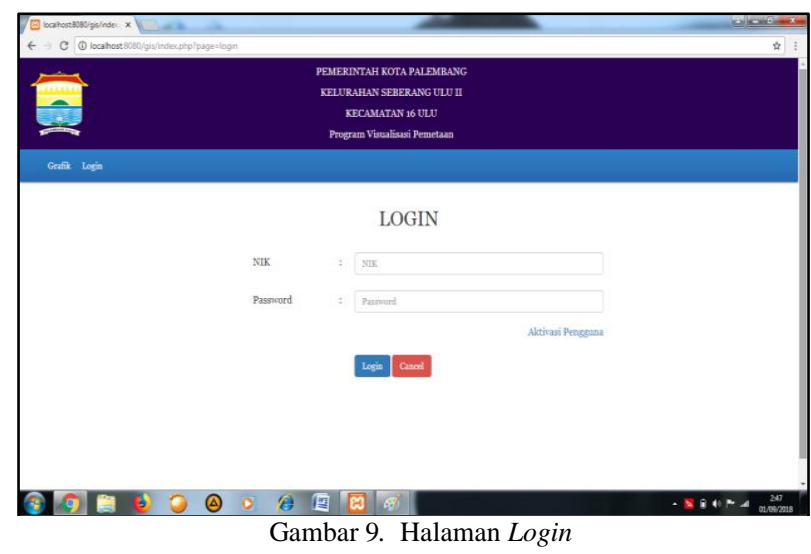

\section{b) Halaman Home}

Halaman ini merupakan tampilan utama saat membuka sistem atau halaman pembukaan sistem. Halaman home dapat dilihat pada gambar. 10 .

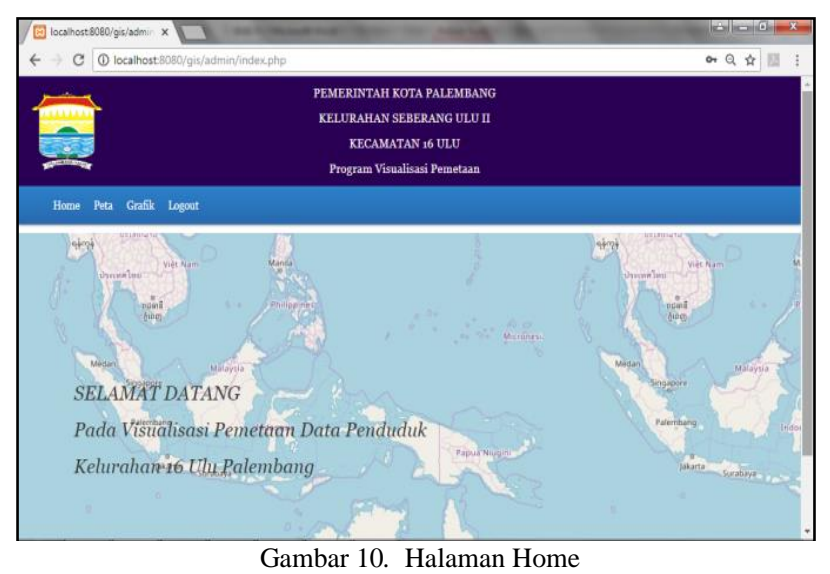

\section{c) Halamn Form Penduduk}

Halaman form penduduk adalah halaman yang digunakan sebagai tempat input dan sebagai tempat edit data penduduk. Halaman form penduduk dapat dilihat pada gambar.11 berikut ini: 


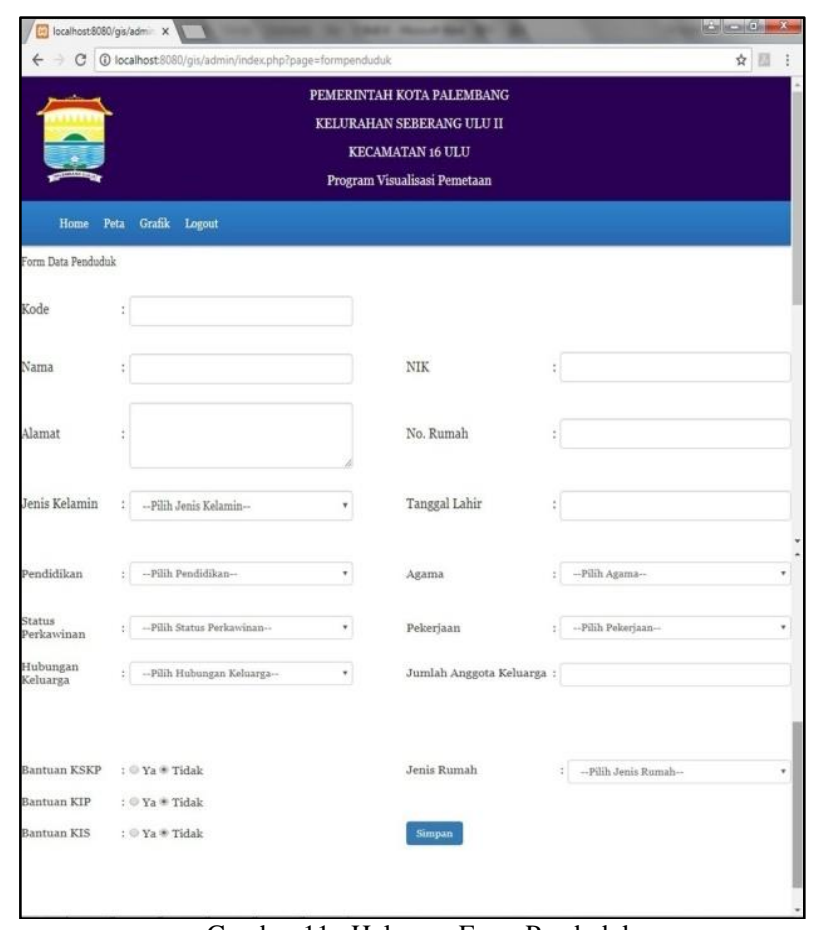

Gambar 11. Halaman Form Penduduk

\section{d) Halaman Data Penduduk}

Merupakan halaman yang berisi rincian data penduduk dan data anggota keluarga. Halaman data penduduk dapat dilihat pada gambar. 12 .

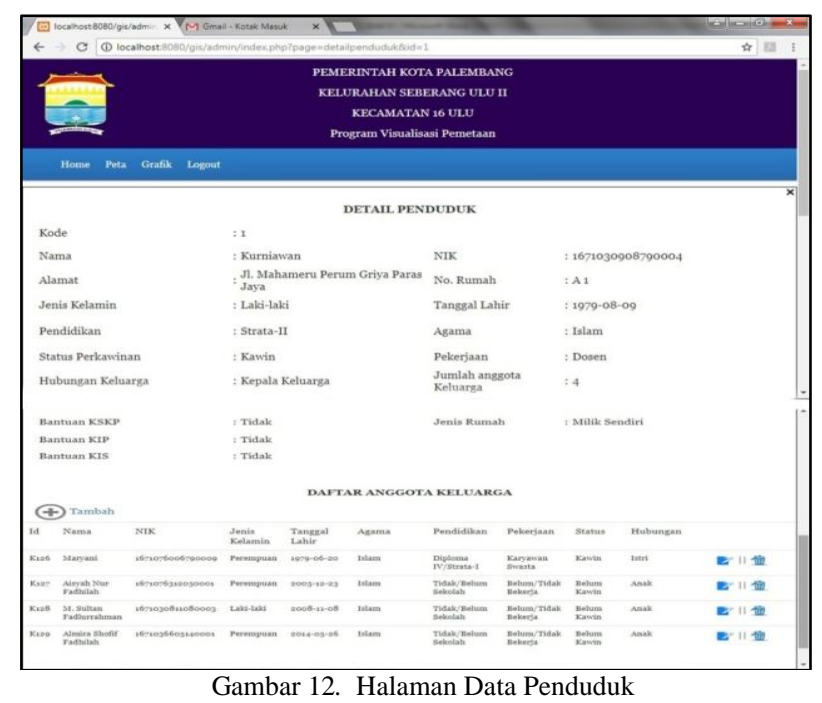

\section{e) Halaman Anggota Keluarga}

Merupakan halaman form anggota keluarga yang digunakan sebagai tempat input data keluarga, halman ini sama seperti halaman form penduduk tetapi terdapat beberapa data yang berbeda dari data penduduk. Halaman anggota keluarga dapat dilihat pada gambar. 13 berikut ini:

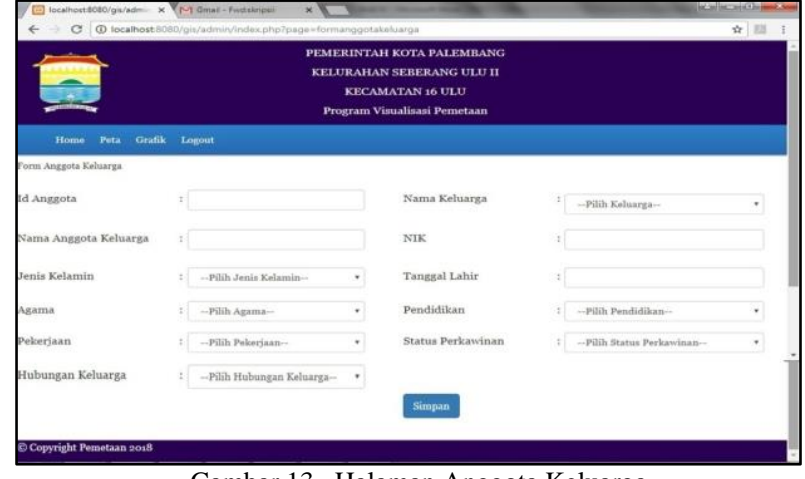

Gambar 13. Halaman Anggota Keluarga

\section{Pengujian}

Pengujian dilakukan dengan menggunakan metode blackbox testing. Black-box testing merupakan pengujian yang berorientasi pada fungsionalitas yaitu perilaku dari perangkat lunak atas input yang diberikan pengguna sehingga mendapatkan/ menghasilkan output yang diinginkan tanpa melihat proses internal atau kode program yang dieksekusi oleh perangkat lunak [10].

Tahap ini dilakukan untuk menguji sistem dari segi fungsional dengan tujuan untuk mengetahui fungsi-fungsi, masukan dan keluaran sistem tanpa menguji desain dan kode program. Hasil pengujian dari sistem visaualisai pemetaan data penduduk adalah sebagai berikut:

1) Pengujian Sistem Visualisasi Pemetaan Penduduk

Hasil dari pengujian sistem dapat dilihat pada tabel II.

TABEL II. PENGUJIAN SISTEM VISUALISASI PEMETAAN

\begin{tabular}{|c|c|c|c|c|}
\hline No & $\begin{array}{c}\text { Aksi yang } \\
\text { Dijalankan }\end{array}$ & $\begin{array}{c}\text { Rancangan } \\
\text { Proses }\end{array}$ & $\begin{array}{c}\text { Hasil yang } \\
\text { Diharapkan }\end{array}$ & $\begin{array}{c}\text { Hasil } \\
\text { Pengujian }\end{array}$ \\
\hline 1 & $\begin{array}{l}\text { Menampilkan } \\
\text { halaman } \\
\text { awal sistem } \\
\text { berupa form } \\
\text { login }\end{array}$ & $\begin{array}{l}\text { Menjalankan } \\
\text { sistem pada } \\
\text { web browser }\end{array}$ & $\begin{array}{l}\text { Menampilkan } \\
\text { halaman awal } \\
\text { berupa halalam } \\
\text { login }\end{array}$ & Bisa \\
\hline 2 & $\begin{array}{l}\text { Halaman } \\
\text { admin }\end{array}$ & $\begin{array}{l}\text { Klik tombol } \\
\text { login }\end{array}$ & $\begin{array}{l}\text { Menampilkan } \\
\text { halaman home } \\
\text { admin }\end{array}$ & Bisa \\
\hline 3 & $\begin{array}{l}\text { Pilih menu } \\
\text { peta }\end{array}$ & $\begin{array}{l}\text { Klik menu } \\
\text { peta }\end{array}$ & $\begin{array}{l}\text { Menampilkan } \\
\text { halaman peta }\end{array}$ & Bisa \\
\hline 4 & $\begin{array}{l}\text { Pilih layer } \\
\text { peta rumah } \\
\text { penduduk }\end{array}$ & $\begin{array}{l}\text { Klik layer dan } \\
\text { check layer } \\
\text { rumah } \\
\text { penduduk }\end{array}$ & $\begin{array}{l}\text { Menampilkan peta } \\
\text { layer rumah } \\
\text { penduduk }\end{array}$ & Bisa \\
\hline 5 & $\begin{array}{l}\text { Pilih layer } \\
\text { peta bantuan } \\
\text { KKS }\end{array}$ & $\begin{array}{l}\text { Klik layer dan } \\
\text { check layer } \\
\text { bantuan KKS }\end{array}$ & $\begin{array}{l}\text { Menampilkan peta } \\
\text { layer bantuan } \\
\text { KKS }\end{array}$ & Bisa \\
\hline 6 & $\begin{array}{l}\text { Pilih layer } \\
\text { peta bantuan } \\
\text { KIP }\end{array}$ & $\begin{array}{l}\text { Klik layer dan } \\
\text { check layer } \\
\text { bantuan KIP }\end{array}$ & $\begin{array}{l}\text { Menampilkan peta } \\
\text { layer bantuan KIP }\end{array}$ & Bisa \\
\hline 7 & $\begin{array}{l}\text { Pilih layer } \\
\text { peta bantuan } \\
\text { KIS }\end{array}$ & $\begin{array}{l}\text { Klik layer dan } \\
\text { check layer } \\
\text { bantuan KIS }\end{array}$ & $\begin{array}{l}\text { Menampilkan peta } \\
\text { layer bantuan KIS }\end{array}$ & Bisa \\
\hline 8 & $\begin{array}{l}\text { Pilih layer } \\
\text { peta jenis }\end{array}$ & $\begin{array}{l}\text { Klik layer dan } \\
\text { check layer }\end{array}$ & $\begin{array}{l}\text { Menampilkan peta } \\
\text { layer jenis agama }\end{array}$ & Bisa \\
\hline
\end{tabular}




\begin{tabular}{|c|c|c|c|c|}
\hline & agama & jenis agama & & \\
\hline 9 & $\begin{array}{l}\text { Pilih layer } \\
\text { peta } \\
\text { pendidikan }\end{array}$ & $\begin{array}{l}\text { Klik layer dan } \\
\text { check layer } \\
\text { pendidikan }\end{array}$ & $\begin{array}{l}\text { Menampilkan peta } \\
\text { layer pendidikan }\end{array}$ & Bisa \\
\hline 10 & $\begin{array}{l}\text { Pilih layer } \\
\text { peta } \\
\text { pekerjaan }\end{array}$ & $\begin{array}{l}\text { Klik layer dan } \\
\text { check layer } \\
\text { pekerjaan }\end{array}$ & $\begin{array}{l}\text { Menampilkan peta } \\
\text { layer pekerjaan }\end{array}$ & Bisa \\
\hline 11 & $\begin{array}{l}\text { Pilih satu } \\
\text { rumah } \\
\text { penduduk }\end{array}$ & $\begin{array}{l}\text { Klik rumah } \\
\text { penduduk } \\
\text { pada peta }\end{array}$ & $\begin{array}{l}\text { Menampilkan } \\
\text { popup informasi } \\
\text { rumah }\end{array}$ & Bisa \\
\hline 12 & $\begin{array}{l}\text { Detail } \\
\text { penduduk }\end{array}$ & $\begin{array}{l}\text { Klik detail } \\
\text { pada popup } \\
\text { peta dirumah } \\
\text { penduduk }\end{array}$ & $\begin{array}{l}\text { Menampilkan } \\
\text { halaman rincian } \\
\text { data penduduk } \\
\text { yang dipilih }\end{array}$ & Bisa \\
\hline 13 & $\begin{array}{l}\text { Form input } \\
\text { data } \\
\text { penduduk }\end{array}$ & $\begin{array}{l}\text { Klik input } \\
\text { pada popup } \\
\text { peta dirumah } \\
\text { penduduk }\end{array}$ & $\begin{array}{l}\text { Menampilkan } \\
\text { halaman form } \\
\text { penduduk }\end{array}$ & Bisa \\
\hline 14 & $\begin{array}{l}\text { Form anggota } \\
\text { keluarga }\end{array}$ & $\begin{array}{l}\text { Klik tambah } \\
\text { pada detail } \\
\text { penduduk }\end{array}$ & $\begin{array}{l}\text { Menampilkan } \\
\text { halaman form } \\
\text { anggota keluarga }\end{array}$ & Bisa \\
\hline 15 & $\begin{array}{l}\text { Grafik } \\
\text { bantuan }\end{array}$ & $\begin{array}{l}\text { Klik menu } \\
\text { grafik }\end{array}$ & $\begin{array}{l}\text { Menampilkan } \\
\text { grafik bantuan } \\
\text { KKS, KIP \& KIS }\end{array}$ & Bisa \\
\hline 16 & Logout & $\begin{array}{l}\text { Klik menu } \\
\text { logout }\end{array}$ & $\begin{array}{l}\text { Menampilkan } \\
\text { halaman awal } \\
\text { berupa halaman } \\
\text { login }\end{array}$ & Bisa \\
\hline
\end{tabular}

[6] Pressman, R.S, "Rekayasa Perangkat Lunak: Pendekatan Praktisi Buku I," Yogyakarta: Andi, 2015.

[7] Sukamto, Rosa Ariani Dan Shalahuddin M, "Rekayasa Perangkat Lunak,” Bandung: Informasi Bandung, 2016.

[8] Rosa, A. S. And M Shalahuddin, "Rekayasa Perangkat Lunak Terstruktur Dan Berorientasi Objek," Bandung: Informatika, 2013.

[9] M. Fairuzabadi And G. K. Priharyanta, "Sistem Informasi Geografis Populasi Penduduk Di Dusun Tegal Kenongo Tirtonirmolo, Kasihan, Bantul, Yogyakarta," Vol. 6, No. 1, P. 19, 2017.

[10] D. Febiharsa, I. M. Sudana, And N. Hudallah, "Uji Fungsionalitas (Blackbox Testing) Sistem Informasi Lembaga Sertifikasi Profesi (Silsp) Batik Dengan Appperfect Web Test Dan Uji Pengguna," Joined J. J. Inform. Educ., Vol. 1, No. 2, P. 10, 2018.

\section{PENUTUP}

Dari hasil penelitian yang telah dilakukan, maka dapat diperoleh kesimpulan bahwa Sistem E-government berbasis GIS yang merupakan visualisasi data penduduk berupa pemetaan terkait dengan informasi detail penduduk dan titik persebaran penduduk telah dibuat sesuai dengan analisis dan perancangannya. Selain itu, sistem ini telah dibangun sesuai dengan tujuan dan manfaatnya dimana sistem dapat membantu pihak kelurahan dalam mengetahui data penduduk disetiap RT, melihat persebaran penduduk di kelurahan Enam-belas Ulu berdasarkan kategori datanya melalui visualisasi data penduduk.

\section{REFERENSI}

[1] D. Napitupulu, "Kajian Faktor Sukses Implementasi E-Government, Studi Kasus: Pemerintah Kota Bogor," Sisfo, Vol. 05, No. 03, Mar. 2015.

[2] E. S. Rachman And B. Noviyanto, "Pemanfaatan E-Government Pada Desa Wonokarto Untuk Meningkatkan Akurasi Dan Informasi Potensi Desa," J. Tam Technol. Accept. Model, Vol. 8, No. 1, P. 6, 2017.

[3] N. Aminudin, "Langkah - Langkah Taktis Pengembangan EGovernment Untuk Pemerintahan Daerah (Pemda) Kabupaten Pringsewu," J. Tam Technol. Accept. Model, Vol. 3, P. 7, 2014.

[4] B. Rahayudi And M. Marji, "Pemetaan Data Dan Visualisasi Kedalaman Air Pada Bendungan / Waduk," J. Teknol. Inf. Dan Ilmu Komput., Vol. 4, P. 111, May 2017.

[5] D. Kurniawati And E. H. Pujiarini, "Pemetaan Industri Kecil Menengah (Ikm) Kabupaten Bantul Berbasis Sistem Informasi Geografis," P. 9, 2016. 